\title{
Inheritance of Major Spathe Colors in Anthurium andraeanum Hort. Is Determined by Three Major Genes
}

\author{
Winston Elibox and Pathmanathan Umaharan ${ }^{1}$ \\ Department of Life Sciences, Faculty of Science and Agriculture, The \\ University of the West Indies, St. Augustine Campus, College Road, St. \\ Augustine, Republic of Trinidad and Tobago
}

Additional index words. anthocyanins, diurnal rhythm, interspecific hybrids, modifier genes, phenylpropanoid pathway, regulatory gene, signal transduction

\begin{abstract}
The inheritance of spathe color in anthurium (Anthurium andraeanum Hort.) was studied in 77 crosses involving 59 parental genotypes. The progeny segregation into "colored : white" did not fit the genetic model proposed by Kamemoto et al. (1988), but fit a duplicate recessive epistasis model involving genes $O$ and $R$, in which either $O$ or $R$ or both in the recessive form would result in white-spathed progeny. The progeny segregation into red or orange group was in agreement with the Kamemoto et al. (1988) model and is determined by the status of the $M$ gene. The dosage effect of particularly the $R$ gene accounted for the differentiation of reds from pinks and oranges from corals. Putative roles for the three genes $(\mathrm{M}, \mathrm{O}$, and $\mathrm{R})$ in the flavonoid biosynthetic pathway are postulated.
\end{abstract}

Modern-day anthurium cultivars are complex interspecific hybrids between Anthurium andraeanum Linden ex André and other species belonging to the section, Calomystrium, and are collectively referred to as $A$. andraeanum (Hort.) (Kamemoto and Kuehnle, 1996). Anthurium is well known for its attractive and long-lasting spathes of various colors, shapes, textures, and sizes, which have contributed to its emergence as an important tropical ornamental crop.

The five major spathe colors of anthurium are red, pink, orange, coral, and white (Kamemoto et al., 1988; Wannakrairoj and Kamemoto, 1990). However, other colors are known such as green, as a result of the presence of chlorophyll; brown, resulting from the copigmentation of orange and green; and spatial bicolors involving green lobes with any of the five major spathe colors in the center (Kamemoto and Kuehnle, 1996). In the global anthurium market, red cultivars are by far the most important (Van Herk et al., 1998), although there has been increasing demand for other colors, bicolors, and patterns (Kamemoto and Kuehnle, 1996) with novelties fetching premium prices (Collette, 2002).

Iwata et al. (1979) reported that the five major spathe colors were determined by

\footnotetext{
Received for publication 8 June 2007. Accepted for publication $12 \mathrm{Feb} .2008$.

This study was funded by the EUFORUM/ CARIFORUM under the Caribbean Agricultural Technology Fund (CARTF) programme.

We thank the management and staff of Kairi Blooms Farm for providing the facilities for the research and Ms. Marilyn Goddard for her technical assistance.

${ }^{1}$ To whom reprint requests should be addressed; e-mail pumaharan@fsa.uwi.tt
}

two anthocyanins, pelargonidin 3-rutinoside (pelargonidin 3-rhamonsylglucoside) and cyanidin 3-rutinoside (cyanidin 3-rhamonsylglucoside), found exclusively in the hypodermal layers of abaxial and adaxial surfaces of the spathe (Ehrenberger and Kuehnle, 2003; Higaki et al., 1984). Pelargonidin 3rutinoside was responsible for orange and coral spathes, whereas both pelargonidin 3rutinoside and cyanidin 3-rutinoside were found in red and pink spathes (Iwata et al., 1979). Coral and pink spathes had anthocyanins in lower concentrations compared with their orange and red counterparts (Iwata et al., 1985). The whites lacked both anthocyanins but contained colorless flavone Cglycosides (Williams et al., 1981).

The genetic basis of the major spathe colors in anthurium was investigated by Kamemoto and Nakasone $(1955,1963)$ and Kamemoto et al. (1968). Kamemoto et al. (1988) produced evidence for two genes, M and $\mathrm{O}$, controlling the major spathe colors in $A$. andraeanum Linden ex André. Recessive epistasis of the $\mathrm{O}$ locus over the $\mathrm{M}$ reflected the biochemical pathway for anthocyanin biosynthesis (Kamemoto et al., 1988). Based on the genetic model of Kamemoto et al. (1988), MmOo, MmOO, MMOo, and MMOO produced red-spathed (red and pink) phenotypes; mmOo and mmOO produced orange-spathed (orange and coral) phenotypes; and mmoo, Mmoo, and MMoo produced white-spathed phenotypes. Furthermore, the dosages of $\mathrm{M}$ and $\mathrm{O}$ genes reflected the range of colors obtained; pink cultivars were postulated to be heterozygous for $\mathrm{M}$ and $\mathrm{O}$ loci, and coral cultivars were heterozygous for the O locus (Kamemoto et al., 1988). It was further postulated that the incremental effect of $\mathrm{M}$ was greater than $\mathrm{O}$ and $\mathrm{mmoo}=$ $\mathrm{Mmoo}=\mathrm{MMoo}<\mathrm{mmOo}<\mathrm{mmOO}<\mathrm{MmOo}$
$<\mathrm{MmOO}<\mathrm{MMOo}<\mathrm{MMOO}$ (Kamemoto et al., 1988).

The genetic model developed by Kamemoto et al. (1988) has not been validated in interspecific hybrids belonging to A. andraeanum (Hort). Furthermore, there is emerging evidence that white-spathed cultivars may be regulatory mutants (Collette, 2002; Collette et al., 2004). The objective of the study is to determine the inheritance of spathe colors based on a large number of broad-based crosses.

\section{Materials and Methods}

Hybridization. Seventy-seven crosses involving 59 parental genotypes were made according to Higaki et al. (1994) during January to April 2000 at Kairi Blooms Ltd., Arima, Trinidad. Each cross was made seven times to generate adequate seeds per cross. Pollinated spadices were covered with brown paper bags after pollination to prevent insect contamination.

Care of seedlings. After 6 to 7 months, ripe yellow berries, each containing one to two green seeds, were harvested and squeezed gently to remove the seeds. The seeds were planted in labeled (name, sowing date) seedling trays containing peatmoss (Premier Horticulture Ltd., Quebec, Canada) and maintained in a nursery house. The nursery was covered with plastic and Saran ( $75 \%$ shade) to protect from sun and rain and was equipped with a mist irrigation and fertigation system. The seedlings were then transplanted in labeled $8-\mathrm{cm}^{2}(8 \mathrm{~cm}$ deep) pots containing peatmoss 6 months after germination. After 1 year, the seedlings were transplanted into labeled $10.5-\mathrm{cm}^{2}(12.5 \mathrm{~cm}$ deep) pots containing peatmoss.

The nursery was watered everyday for $10 \mathrm{~s}$ at 15 -minute intervals between 0900 and 1600 HR. The plants were fertilized ( $450 \mathrm{~g}$ per plot) on a monthly basis with either triple superphosphate (Keisurit, Regenstauf, Germany) or $12 \mathrm{~N}-11 \mathrm{P}-13 \mathrm{~K}$ (Norsk Hydro Olje AB, NYBRO, Sweden). The $\mathrm{pH}$ of the growing media was maintained at 5.5 by continuous monitoring and applying calcium carbonate (Limestone; TRINCARB, Port of Spain, Trinidad), as required. The nematicide, Temik (Aldicarb, Shandong, China), was applied once to prevent nematode infestation.

The resulting 3372 seedlings were assessed for spathe color over at least six harvests. For purposes of simplicity, all white-spathed and green-spathed seedlings (genotypes) that possessed no anthocyanin (Ehrenberger and Kuehnle, 2003) were recorded as white, whereas the others were grouped into the major spathe color groups, red and orange, according to Kamemoto et al. (1988) and Kamemoto and Kuehnle (1996) and used in genetic analysis.

Genetic analysis. Chi-squared tests (with Yates' correction) were carried out to test the observed segregation ratio of colored versus white for the various white $\times$ white and white $\times$ colored spathe crosses against expected ratios based on a number of genetic models 
including that of Kamemoto et al. (1988). Subsequently, the segregation ratios of various colored $\times$ colored crosses were tested against plausible genetic models to determine the inheritance of spathe colors.

\section{Results}

White $\times$ white crosses. None of the progenies derived from these crosses fit (Table 1) the expected $0: 1$ colored:white $(\mathrm{C}: \mathrm{W})$ ratio based on the Kamemoto et al. (1988) model. Four of the five crosses fit a two-gene duplicate recessive epistasis model (1:3; $1: 1)$ and all five fit a two-gene dominant and recessive epistasis model $(1: 3 ; 1: 1,1: 7$, and $3: 13$ ). Significantly, both new models allow colored spathe progenies to be produced from crosses between white-spathed cultivars, which is not possible under the Kamemoto et al. (1988) model.

The proposed new models were different from the model of Kamemoto et al. (1988) in that an additional gene, $\mathrm{R}$, is required in addition to the structural genes $\mathrm{M}$ and $\mathrm{O}$ proposed by Kamemoto et al. (1988). In the dominant and recessive epistasis model, the gene $\mathrm{R}$ in the dominant form (R-) repressed the $\mathrm{O}$ gene regardless of its genotypic form to produce white-spathed flowers. Hence, O-R-, ooR-, and oorr should be white-spathed and O-rr should be colored-spathed. In the duplicate recessive epistasis model, the $\mathrm{R}$ gene or $\mathrm{O}$ gene, or both, in the homozygous recessive form suppressed color formation. Hence, genotypes ooR-, oorr, and O-rr should be white-spathed and O-R- should be coloredspathed.

Colored $\times$ white crosses. The progeny of these crosses fit the expected $\mathrm{C}: \mathrm{W}$ ratios of $1: 0,1: 1,3: 1$, or $3: 5$ (Table 2), which are all plausible under the two-gene duplicate recessive and the two-gene dominant and recessive epistasis models. However, only $1: 1$ and $1: 0$ ratios are plausible under the Kamemoto et al. (1988) model. Theoretical analysis showed that the $1: 0(\mathrm{C}: \mathrm{W})$ ratio would be the most frequent result to be expected with the two-gene duplicate recessive epistasis model (data not shown), which was in fact the case in this study. On the other hand, the $1: 0(\mathrm{C}: \mathrm{W})$ ratio would be theoretically expected at a low frequency of 0.07 based on the two-gene dominant and recessive epistasis model. Hence, the results from the colored $\times$ white crosses support the duplicate recessive epistasis model.

Theoretical analyses also showed that the $1: 0(\mathrm{C}: \mathrm{W})$ ratio between colored and white crosses would be predominantly obtained when the colored parent has a genotype of OORR (data not shown). Notably, the $1: 0$ (C $:$ W) ratio for the colored $\times$ white crosses was predominantly seen in the red $\times$ white and orange $\times$ white crosses, whereas all the ratios were equally frequent among the pink $\times$ white crosses (Table 2). Of the 23 colored $x$ white crosses that gave a $1: 0(\mathrm{C}: \mathrm{W})$ segregation ratio, only 10 fit perfectly (Table $2)$. In the other cases, one to a few white-
Table 1. Anthurium andraeanum (Hort.) progeny spathe color segregation ratios (color: white) for six white-spathed $\times$ white-spathed cultivar crosses.

\begin{tabular}{llcccccc}
\hline Female & \multicolumn{1}{c}{ Male } & Color & White & Total & Fitted ratio & $\chi^{2}$ & Probability \\
\hline Bianca & Pierrot & 19 & 24 & 43 & $1: 1$ & 0.372 & $0.50-0.70$ \\
Pierrot & Priscilla & 15 & 34 & 49 & $1: 3$ & 0.551 & $0.30-0.50$ \\
Local Mina & Cuba & 10 & 67 & 77 & $1: 7$ & $0.002 ; 5.305$ & $0.95-0.975 ; 0.02-0.025$ \\
$\quad$ White & & & & & $1: 3$ & & \\
Ibara & Cross 4044 & 4 & 30 & 34 & $1: 7$ & $0.017 ; 2.509$ & $0.80-0.90 ; 0.10-0.20$ \\
& & & & & $1: 3$ & & \\
Champagne & Pierrot & 16 & 75 & 91 & $3: 13$ & $0.018 ; 2.289$ & $0.80-0.90 ; 0.10-0.20$ \\
& & & & & $1: 3$ & & \\
\hline
\end{tabular}

Table 2. Anthurium andraeanum (Hort.) progeny spathe color segregation ratios (color: white) for 34 colored- $\times$ white-spathed cultivar crosses.

\begin{tabular}{|c|c|c|c|c|c|c|c|}
\hline Female & Male & Color & White & Total & Fitted ratio & $\chi^{2}$ & $\overline{\text { Probability }}$ \\
\hline$\overline{\text { Midori }(w)^{z}}$ & Venus $(\mathrm{c})^{\mathrm{y}}$ & 20 & 0 & 20 & $1: 0$ & 0.000 & 1.00 \\
\hline Fantasia (w) & Venus (c) & 32 & 2 & 34 & $1: 0$ & & \\
\hline Champagne (w) & Venus (c) & 51 & 0 & 51 & $1: 0$ & 0.000 & 1.00 \\
\hline Pierrot (w) & Venus (c) & 52 & 0 & 52 & $1: 0$ & 0.000 & 1.00 \\
\hline Local Orange (o) & Cuba (w) & 104 & 0 & 104 & $1: 0$ & 0.000 & 1.00 \\
\hline Acropolis (w) & Hawaii $(0)^{x}$ & 72 & 5 & 77 & $1: 0$ & & \\
\hline Fantasia (w) & Hawaii (o) & 32 & 3 & 35 & $1: 0$ & & \\
\hline Pierrot (w) & Local Orange (o) & 50 & 9 & 59 & $1: 0$ & & \\
\hline Champagne (w) & Hawaii (o) & 31 & 3 & 34 & $1: 0$ & & \\
\hline Laguna (w) & Sonate $(\mathrm{p})^{\mathrm{w}}$ & 27 & 13 & 40 & $3: 1$ & 0.833 & $0.30-0.50$ \\
\hline Champagne(w) & Victoria (p) & 17 & 13 & 30 & $1: 1$ & 0.300 & $0.50-0.70$ \\
\hline Champagne (w) & Sonate (p) & 15 & 7 & 22 & $3: 1$ & 0.243 & $0.50-0.70$ \\
\hline $\operatorname{LWP}^{\mathrm{v}}(\mathrm{p})$ & Pierrot (w) & 35 & 64 & 99 & $3: 5$ & 0.115 & $0.70-0.75$ \\
\hline Cuba (w) & Local Pink (p) & 16 & 28 & 44 & $3: 5$ & 0.000 & 1.00 \\
\hline Laguna (w) & Local Pink (p) & 16 & 14 & 30 & $1: 1$ & 0.034 & $0.80-0.90$ \\
\hline Champagne (w) & Cross $3962(\mathrm{p})$ & 46 & 4 & 50 & $1: 0$ & & \\
\hline New Pink 2 (p) & Pierrot (w) & 22 & 1 & 23 & $1: 0$ & & \\
\hline Cuba (w) & Pastora (p) & 35 & 3 & 38 & $1: 0$ & & \\
\hline Champagne (w) & Lydia (p) & 16 & 5 & 21 & $3: 1$ & 0.016 & $0.80-0.90$ \\
\hline $\operatorname{Rosa}(\mathrm{p})$ & Acropolis (w) & 11 & 14 & 25 & $1: 1$ & 0.160 & $0.50-0.70$ \\
\hline Acropolis (w) & Victoria (p) & 40 & 38 & 78 & $1: 1$ & 0.012 & $0.90-0.95$ \\
\hline Midori (w) & Sweety $(r)^{\mathrm{u}}$ & 25 & 11 & 36 & $3: 1$ & 0.333 & $0.50-0.70$ \\
\hline Laguna (w) & $\operatorname{LMR}^{\mathrm{t}}(\mathrm{r})$ & 37 & 0 & 37 & $1: 0$ & 0.000 & 1.00 \\
\hline Cuba (w) & Success (r) & 37 & 8 & 45 & $3: 1$ & 0.896 & $0.30-0.50$ \\
\hline LMR (r) & Cuba (w) & 45 & 1 & 46 & $1: 0$ & & \\
\hline Mirjam (r) & Cuba (w) & 26 & 0 & 26 & $1: 0$ & 0.000 & 1.00 \\
\hline Mirjam (r) & Ibara (w) & 33 & 0 & 33 & $1: 0$ & 0.000 & 1.00 \\
\hline Gloria (r) & Pierrot (w) & 99 & 0 & 99 & $1: 0$ & 0.000 & 1.00 \\
\hline Champagne (w) & Gloria (r) & 23 & 0 & 23 & $1: 0$ & 0.000 & 1.00 \\
\hline Acropolis (w) & Gloria (r) & 39 & 1 & 40 & $1: 0$ & & \\
\hline Mirjam (r) & Tequila (w) & 17 & 1 & 18 & $1: 0$ & & \\
\hline Champagne (w) & Honduras (r) & 103 & 8 & 111 & $1: 0$ & & \\
\hline Honduras (r) & Cuba (w) & 26 & 1 & 27 & $1: 0$ & & \\
\hline Cross $4038(\mathrm{r})$ & Cross $442(\mathrm{w})$ & 28 & 0 & 28 & $1: 0$ & 0.000 & 1.00 \\
\hline
\end{tabular}

${ }^{\mathrm{z}}$ White-spathed anthurium cultivar.

${ }^{y}$ Coral-spathed anthurium cultivar.

${ }^{x}$ Orange-spathed anthurium cultivar.

wPink-spathed anthurium cultivar.

'Local Whitish Pink.

"Red-spathed anthurium cultivar.

tLocal Mina Red.

spathed progenies was found against a large number of colored ones.

Colored $\times$ colored crosses. The progeny of these crosses (Table 3 ) produced ratios 1 : 0 and $3: 1$, of which the $1: 0(\mathrm{C}: \mathrm{W})$ ratio was by far the most frequent $(80 \%)$ as was expected with all three genetic models. Twenty of the 31 colored $\times$ colored crosses that produced a $1: 0(\mathrm{C}: \mathrm{W})$ ratio fit perfectly, whereas the remainder had one or a few spurious white progenies (Table 3 ). In general, a duplicate recessive epistasis model was able to explain the segregation $(\mathrm{C}: \mathrm{W})$ patterns of almost all of the crosses investigated in this study.

Segregation of colors. The specific segregation of the colors into red and orange groups in the progenies followed that of
Kamemoto et al. (1988), in which MM and $\mathrm{Mm}$ should result in spathe colors belonging to the red group, whereas mm should lead to spathe colors belonging to the orange group.

Of the 77 crosses investigated, 52 produced good fits to the proposed ratios and another 10 had just one spurious orangespathed progeny (data not shown). Therefore, in total, $\approx 81 \%$ of the crosses fit the Kamemoto et al. (1988) model for segregation of colored spathes. Genotypes were assigned to each cultivar by trial and error based on crosses that each cultivar was involved in. Based on the genotype assignment to cultivars, white cultivars could be $\mathrm{mm}, \mathrm{Mm}$, and $\mathrm{MM}$; all coral and orange cultivars were $\mathrm{mm}$; and pink and red cultivars were assigned either MM or Mm (Table 4). 
Table 3. Anthurium andraeanum (Hort.) progeny spathe color segregation ratios (color: white) for 38 colored- $\times$ colored-spathed cultivar crosses.

\begin{tabular}{|c|c|c|c|c|c|c|c|}
\hline Female & Male & Color & White & Total & Fitted ratio & $\chi^{2}$ & Probability \\
\hline Local Orange $(\mathrm{o})^{\mathrm{z}}$ & Gloria $(\mathrm{r})^{\mathrm{y}}$ & 18 & 0 & 18 & $1: 0$ & 0.000 & 1.00 \\
\hline Mirjam (r) & Hawaii (o) & 11 & 0 & 11 & $1: 0$ & 0.000 & 1.00 \\
\hline Kalapana (r) & Hawaii (o) & 23 & 0 & 23 & $1: 0$ & 0.000 & 1.00 \\
\hline Local Orange (o) & Honduras (r) & 95 & 0 & 95 & $1: 0$ & 0.000 & 1.00 \\
\hline Sonate $(p)^{x}$ & Terra (o) & 22 & 6 & 28 & $3: 1$ & 0.048 & $0.80-0.90$ \\
\hline Senator $(c)^{\mathrm{w}}$ & Victoria (p) & 22 & 7 & 29 & $3: 1$ & 0.012 & $0.90-0.95$ \\
\hline Senator (c) & New obake (p) & 26 & 8 & 34 & $3: 1$ & 0.000 & 1.00 \\
\hline Cross 2794 (p) & Marissa (c) & 45 & 5 & 50 & $1: 0$ & & \\
\hline Cross $4414(\mathrm{p})$ & Cross $3858(\mathrm{p})$ & 34 & 1 & 35 & $1: 0$ & & \\
\hline Lydia (p) & New Obake (p) & 59 & 5 & 64 & $1: 0$ & & \\
\hline Cross $2918(\mathrm{p})$ & Cross $800(\mathrm{p})$ & 31 & 0 & 31 & $1: 0$ & 0.000 & 1.00 \\
\hline Spirit (p) & Lydia (p) & 19 & 2 & 21 & $1: 0$ & & \\
\hline Cross $4062(\mathrm{p})$ & $\operatorname{LMP}^{\mathrm{v}}(\mathrm{p})$ & 28 & 2 & 30 & $1: 0$ & & \\
\hline Lydia (p) & Cross 3962 (p) & 84 & 1 & 85 & $1: 0$ & & \\
\hline Lydia (p) & Local Pink (p) & 31 & 2 & 33 & $1: 0$ & & \\
\hline Cross $2520(\mathrm{p})$ & Cross 3942 (p) & 22 & 0 & 22 & $1: 0$ & 0.000 & 1.00 \\
\hline Rosa (p) & $\operatorname{LMR}^{\mathrm{u}}(\mathrm{r})$ & 25 & 0 & 25 & $1: 0$ & 0.000 & 1.00 \\
\hline Gloria (r) & LMP (p) & 39 & 0 & 39 & $1: 0$ & 0.000 & 1.00 \\
\hline Cross 3023 (r) & Cross 2135 (p) & 75 & 0 & 75 & $1: 0$ & 0.000 & 1.00 \\
\hline Alexis (r) & Cumbia (p) & 68 & 7 & 75 & $1: 0$ & & \\
\hline Lydia (p) & Honduras (r) & 22 & 0 & 22 & $1: 0$ & 0.000 & 1.00 \\
\hline Cross 868 (r) & Cross $3476(\mathrm{p})$ & 40 & 11 & 51 & $3: 1$ & 0.164 & $0.50-0.70$ \\
\hline Alexis (r) & Sonate $(p)$ & 21 & 7 & 28 & $3: 1$ & 0.000 & 1.00 \\
\hline Cross $3071(\mathrm{p})$ & Cross 3864 (r) & 25 & 5 & 30 & $3: 1$ & 0.711 & $0.30-0.50$ \\
\hline Alexis (r) & Local Pink (p) & 35 & 21 & 56 & $3: 1$ & 4.024 & $0.025-0.05$ \\
\hline Honduras (r) & Cross 3962 (p) & 27 & 0 & 27 & $1: 0$ & 0.000 & 1.00 \\
\hline Cross $2679(\mathrm{p})$ & Cross 4038 (r) & 19 & 2 & 21 & $1: 0$ & & \\
\hline LMR (r) & Gloria (r) & 24 & 0 & 24 & $1: 0$ & 0.000 & 1.00 \\
\hline Cross 163 (r) & Cross 793 (r) & 25 & 0 & 25 & $1: 0$ & 0.000 & 1.00 \\
\hline Kalapana (r) & LMR (r) & 30 & 0 & 30 & $1: 0$ & 0.000 & 1.00 \\
\hline Mirjam (r) & Kalapana (r) & 45 & 0 & 45 & $1: 0$ & 0.000 & 1.00 \\
\hline Mirjam (r) & Gloria (r) & 43 & 0 & 43 & $1: 0$ & 0.000 & 1.00 \\
\hline Mirjam (r) & Alexis (r) & 34 & 0 & 34 & $1: 0$ & 0.000 & 1.00 \\
\hline Gloria (r) & Honduras (r) & 40 & 3 & 43 & $1: 0$ & & \\
\hline Honduras (r) & LMR (r) & 91 & 0 & 91 & $1: 0$ & 0.000 & 1.00 \\
\hline Local Orange (o) & Terra (o) & 21 & 0 & 21 & $1: 0$ & 0.000 & 1.00 \\
\hline Senator (c) & Hawaii (o) & 79 & 6 & 85 & $1: 0$ & & \\
\hline Local Orange (o) & Venus (c) & 44 & 0 & 44 & $1: 0$ & 0.000 & 1.00 \\
\hline
\end{tabular}

${ }^{\mathrm{z}}$ Orange-, ${ }^{\mathrm{y}}$ red-, ${ }^{\mathrm{x}}$ pink-, and ${ }^{\mathrm{w}}$ coral-spathed anthurium cultivar.

'Local Mina Pink.

"Local Mina Red.

\section{Discussion}

There is compelling evidence from this study that the model of Kamemoto et al. (1988) may not be adequate in explaining the segregation of colors and whites. First, the white $\times$ white crosses produced segregation ratios other than the expected $0: 1(\mathrm{C}: \mathrm{W})$ ratio based on the Kamemoto et al. (1988) model (Table 1). It is noteworthy that the $0: 1$ $(\mathrm{C}: \mathrm{W})$ ratio in white $\times$ white anthurium crosses is obtained only when either gene $\mathrm{O}$ or $\mathrm{R}$ is in the homozygous recessive state in both the parents based on the duplicate recessive epistasis model. In modern-day anthurium cultivars, which are based on interspecific hybridization, it is highly probable that the loci are heterozygous at least in one of the parents, accounting for our results. Second, color $\times$ white crosses (Table 2) produced a wide range of ratios, including $3: 1,3: 5$, and $1: 3$; and the color $\times$ color crosses (Table 3 ) produced $1: 0$ and $3: 1$ (C: $\mathrm{W})$ ratios. These particular ratios are not expected based on the Kamemoto et al. (1988) model. Third, the dosage effect proposed for the M gene (Kamemoto et al., 1988) to explain the difference between reds and pinks did not fit our results (Table 4).
On the other hand, a duplicate recessive epistasis model involving two genes designated $\mathrm{O}$ and $\mathrm{R}$ was able to explain the segregation of colors and whites in progenies of most white $x$ white crosses and all white $x$ color and color $\times$ color crosses. Further evidence for this model comes from its ability to explain the uniform $1: 0$ ratio obtained for red $\times$ red and orange $\times$ orange crosses but various ratios for pink $\times$ pink crosses. The model can also be used to explain the emergence of pinks and corals, which is discussed later. There were, however, some unusual results. A few spurious whites emerged in some color $\times$ color crosses, in which only colored progenies were expected based on the duplicate recessive epistasis model involving the $\mathrm{O}$ and $\mathrm{R}$ genes. These may have been contaminants (Kamemoto et al., 1988 ) or suggest the involvement of other minor modifier genes.

In the duplicate recessive model, either the $\mathrm{R}$ or $\mathrm{O}$ gene, or both $\mathrm{R}$ and $\mathrm{O}$ genes in the homozygous recessive forms, will result in white-spathed anthurium. In other words, the presence of genes $\mathrm{O}$ and $\mathrm{R}$ in the dominant forms (O-, R-) is required for colored genotypes to be obtained. The nature of the color, whether it belongs to the red group or the orange group, is decided by the status of the $\mathrm{M}$ gene and is in accordance with Kamemoto et al. (1988). For instance, this gene (M-) in the dominant form resulted in the red group of colors, whereas in its recessive form $(\mathrm{mm})$, it produced the orange group of colors.

To further understand these results, it is necessary to relate the proposed genes based on this study to genes in the phenylpropanoid biosynthetic pathway, the pathway that leads to the formation of spathe colors in anthurium (Collette, 2002). Jaakola et al. (2002) stated that two classes of genes are required for anthocyanin biosynthesis, the structural genes encoding the enzymes that directly participate in the formation of anthocyanins and other flavonoids and regulatory genes that control the transcription of the structural genes. Collette (2002) showed that the flavonoid biosynthetic genes in anthurium are regulated by two separate regulatory systems, one simultaneously regulating a number of genes including $\mathrm{CHS}, \mathrm{F} 3 \mathrm{H}$, and ANS and another specifically targeting the DFR gene. Anthocyanin production was found to be concomitant with DFR expression, indicating that DFR expression may serve as a point of regulation for anthocyanin biosynthesis. Collette (2002) identified a candidate Myb gene in anthurium that is a possible transcriptional activator of the DFR gene. In addition, an unknown regulatory gene simultaneously suppressed the transcript levels of the structural genes $\mathrm{CHS}, \mathrm{F} 3 \mathrm{H}$, and ANS in the white anthurium cultivar, 'Acropolis' (Collette, 2002). The study (Collette, 2002) suggested that the whites were regulatory mutants rather than structural mutants.

It is suggested that the two genes, $\mathrm{O}$ and $\mathrm{R}$, found in this study to be the determinants of color in anthurium correspond to the two regulatory systems proposed by Collette (2002). For instance, the dominant $\mathrm{R}$ gene could operate as a transcriptional activator of the regulatory cascade involving genes $\mathrm{CHS}$, $\mathrm{F} 3 \mathrm{H}$, and $\mathrm{ANS}$, whereas the dominant $\mathrm{O}$ gene may function as the transcriptional activator of the DFR gene. Hence, either the R or O gene in the homozygous recessive state will prevent the formation of anthocyanins responsible for colors. For the same reasons, when both the $\mathrm{R}$ and $\mathrm{O}$ genes are in the recessive form (as found for 'Acropolis' in this study), the genes CHS, F3H, DFR, and ANS will be suppressed, as was observed for 'Acropolis' by Collette (2002). Similarly, two petunia regulators, an 1 and/or an 11 , lead to a complete loss of expression of their target anthocyanin genes in all pigmented tissues and consequently lead to completely white petunia flowers (Dooner et al., 1991; Quattrocchio et al., 1993). Regulatory genes in the anthocyanin biosynthetic pathway have also been reported in the genus, Antirrhinum (Sablowski et al., 1994), grapes (Vitis species) (Boss et al., 1996), apple (Malus species) fruit (Kondo et al., 2002), and maize (Zea mays) (Tuerck and Fromm, 1994).

In maize (Zea mays), two transcription factors (a MYB-related protein and a 
Table 4. The plausible genotypes, with respect to the hypothetical, O, R, and M loci, for Anthurium andraeanum (Hort.) cultivars belonging to various flower color groups.

\begin{tabular}{|c|c|c|c|}
\hline$\overline{\text { Color }}$ & Cultivar & Genotype for $\mathrm{O}$ and $\mathrm{R}$ & Genotype for $M$ \\
\hline \multirow[t]{2}{*}{$\overline{\text { Coral }}$} & Senator & OORr, OoRr & $\mathrm{mm}$ \\
\hline & Venus & OORR & $\mathrm{mm}$ \\
\hline \multirow[t]{3}{*}{ Orange } & Hawaii & OORR & $\mathrm{mm}$ \\
\hline & Local Orange & OORR & $\mathrm{mm}$ \\
\hline & Terra & OoRr, OORr & $\mathrm{mm}$ \\
\hline \multirow[t]{13}{*}{ Pink } & Cross 3962 & OORR & $\mathrm{Mm}$ \\
\hline & Cumbia & OORR, OORr & $\mathrm{Mm}$ \\
\hline & Local Whitish Pink & OoRr & MM \\
\hline & Local Mina Pink & OoRr, OORr & MM \\
\hline & Local Pink & OoRR & $\mathrm{Mm}$ \\
\hline & Lydia & OORr & MM \\
\hline & New obake & OoRR & $\mathrm{Mm}$ \\
\hline & New Pink 2 & OORR & MM \\
\hline & Pastora & OORR & $\mathrm{Mm}$ \\
\hline & Rosa & OORr & MM \\
\hline & Sonate & OORr & MM \\
\hline & Spirit & OoRR & $\mathrm{Mm}$ \\
\hline & Victoria & OORr & MM \\
\hline \multirow[t]{10}{*}{ Red } & Alexis & OoRr & MM \\
\hline & Cross 163 & OoRR & $\mathrm{Mm}$ \\
\hline & Cross 793 & OORr & $\mathrm{Mm}$ \\
\hline & Gloria & OORR & $\mathrm{Mm}$ \\
\hline & Honduras & OORR & MM \\
\hline & Kalapana & OORR, OoRR & $\mathrm{Mm}$ \\
\hline & Local Mina Red & OORR & $\mathrm{Mm}$ \\
\hline & Mirjam & OORR & $\mathrm{Mm}$ \\
\hline & Success & OoRR & $\mathrm{Mm}$ \\
\hline & Sweety & OoRR & $\mathrm{Mm}$ \\
\hline \multirow[t]{10}{*}{ White } & Acropolis & oorr & $\mathrm{mm}$ \\
\hline & Bianca & Oorr & MM \\
\hline & Champagne & Oorr & $\mathrm{Mm}$ \\
\hline & Cuba & $\mathrm{ooRr}$ & $\mathrm{Mm}$ \\
\hline & Laguna & $o o R r$ & $\mathrm{Mm}$ \\
\hline & Linda & $o o R r$ & MM \\
\hline & Local Mina White & Oorr & MM \\
\hline & Midori & Oorr & $\mathrm{mm}$ \\
\hline & Pierrot & $\mathrm{ooRr}$ & $\mathrm{Mm}$ \\
\hline & Priscilla & Oorr & MM \\
\hline
\end{tabular}

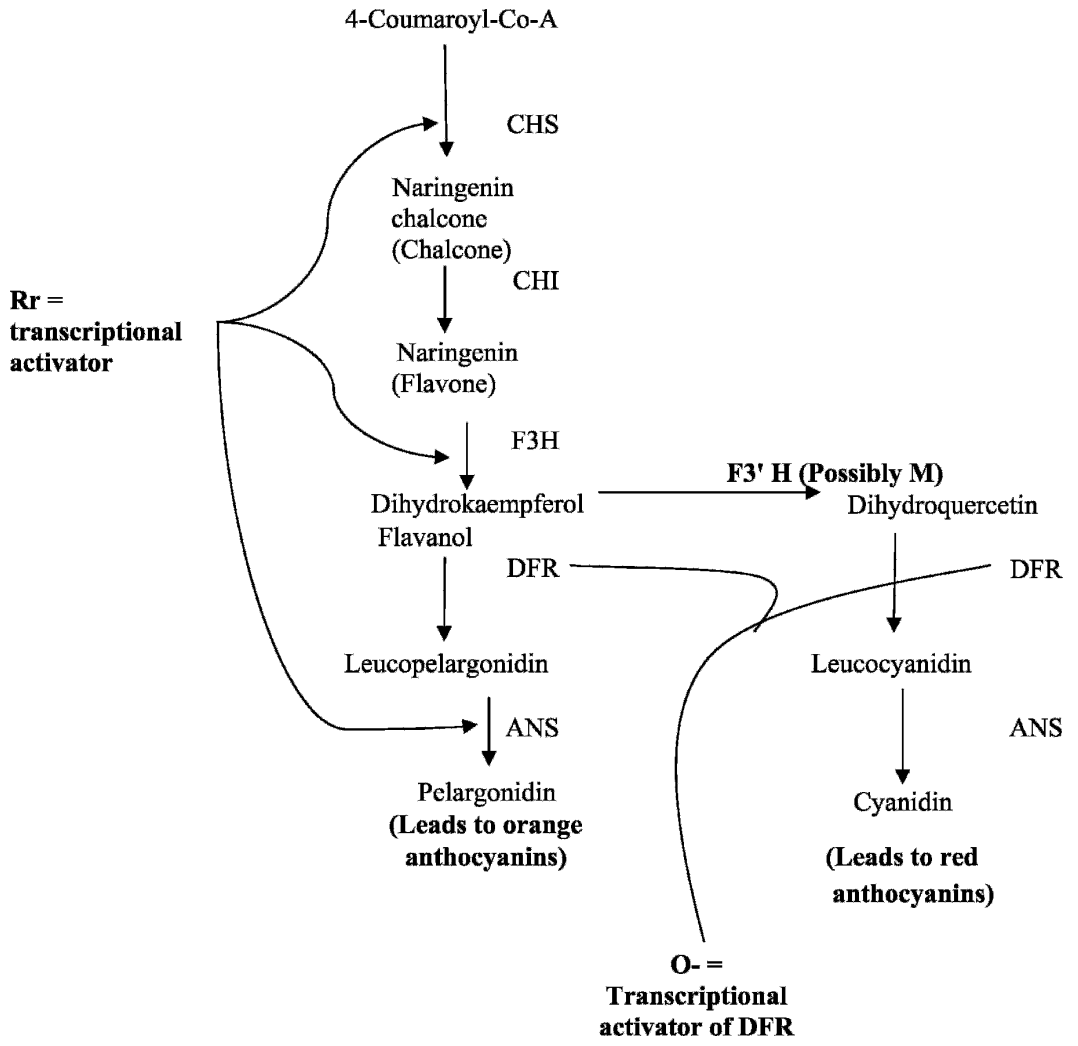

Fig. 1. Proposed genetic model for spathe color in Anthurium andraeanum (Hort.) based on proposed model with genes $\mathrm{M}, \mathrm{O}$, and $\mathrm{R}$.
bHLH-containing protein) have been shown to interact to activate genes in the anthocyanin biosynthetic pathway (Cone et al., 1986, 1993; Grotewold et al., 2000). In Antirrhinum majus, the molecular characterization of 'delila' demonstrated that gene products similar to those in maize regulate anthocyanin production in dicotyledonous species (Goodrich et al., 1992). This has also been shown to be the case for flowers of other dicotyledonous species such as Ipomoea purpurea and Ipomoea tricolor (Chang et al., 2005; Park et al., 2004). If O and R each control a separate step as our study suggests, it may well be that in Anthurium, only one of the two transcription factors regulating each step is segregating.

The three putative genetic factors controlling spathe color, therefore, are M, determining whether pelargonidin 3-rutinoside (orange) or cyanidin 3-rutinoside (red) are produced; and $\mathrm{O}$ and $\mathrm{R}$, controlling whether anthocyanins are produced. It is proposed that the putative regulator of $\mathrm{CHS}, \mathrm{F} 3 \mathrm{H}$, and ANS is the $\mathrm{R}$ gene and the putative regulator of the DFR gene is the $\mathrm{O}$ gene. The most likely candidate for $\mathrm{M}$ is $\mathrm{F}^{\prime}{ }^{\prime} \mathrm{H}$, a structural gene that converts dihydrokaempferol, responsible for the formation of orange pelargonidin 3-rutinoside, to dihydroquercetin, responsible for the formation of the red, cyanidin 3-rutinoside (Collette, 2002).

The fact that the pinks and reds, belonging to the red group, were found to be either Mm or MM in this study suggests that dosage effects could not account for the difference as suggested by Kamemoto et al. (1988). It is therefore more likely that $\mathrm{O}$ and $\mathrm{R}$ genes are somehow involved in their determination. When a genotype at the $\mathrm{O}$ and $\mathrm{R}$ loci were OORR, then dark red spathes were obtained when the M locus was either MM or Mm and an orange spathe when the M locus was homozygous recessive $(\mathrm{mm})$. Lighter shades of red such as with the anthurium cultivars, 'Sweety' and 'Success', were obtained when the genotype for the $\mathrm{O}$ and $\mathrm{R}$ loci was OoRR. Hence, with the exception of the cultivar 'Alexis', it appears that reds are generally O-RR. In contrast, eight of the 12 pink cultivars were O-Rr. Where pinks were OoRR such as Local Pink, a deeper pink was obtained. This suggests that the R locus appears to exert a strong dosage effect depending on the number of dominant alleles it possesses. Similarly, the darker orangespathed cultivars were mmOORR and the corals were generally $\mathrm{mmOORr}$, with the exception of cultivar, 'Terra'. More controlled crosses need to be carried out to verify these results.

Anthurium flowers have an extended flower development period of 8 to 9 weeks (Collette, 2002). The genes CHS, F3H, and ANS are expressed constitutively, whereas the DFR gene shows a distinct gene expression pattern (Collette et al., 2004) with a marked increase in transcript level at stage 3 followed by a significant decline between stages 4 and 6 . The expression of CHS, F3H, and ANS were quantitatively lower in the 
pinks compared with the reds and oranges at all stages of development (Collette, 2002; Collette et al., 2004). The DFR accumulation was also delayed to stage 6 in the pinks compared with stage 3 in the reds and oranges (Collette, 2002; Collette et al., 2004).

The dosage effect of the $\mathrm{R}$ gene can be explained by the proposed molecular model of Collette (2002) and Collette et al. (2004). If the $\mathrm{R}$ gene is as proposed, a transcriptional activator of the CHS, ANS, and $\mathrm{F} 3 \mathrm{H}$ genes, and is expressed constitutively (Collette et al., 2004), then a heterozygous $\mathrm{Rr}$ may reduce the amount of dihydrokaempferol available for the $\mathrm{M}$ gene (possible $\mathrm{F}^{\prime}{ }^{\prime} \mathrm{H}$ ) and the $\mathrm{O}$ gene (possibly the regulator of the DFR gene) resulting in lower levels of anthocyanins. Under limited levels of dihydrokaempferol (Rr), the differences between $\mathrm{MM}$ and $\mathrm{Mm}$ as well as $\mathrm{OO}$ and Oo will not be as evident as when the $\mathrm{R}$ gene is RR. Hence, the proposed model is consistent with the molecular model and can explain the formation of pinks and corals.

The genetic/molecular model proposed is summarized in Figure 1. At present, we are conducting molecular biological investigations to confirm this model and to identify the candidate genes. The understanding of the molecular and genetic control model for anthurium flower color and the genotyping of parents will allow greater control in manipulating colors in breeding programs.

\section{Literature Cited}

Boss, P.K., C. Davies, and S.P. Robinson. 1996. Expression of anthocyanin biosynthesis pathway genes in red and white grapes. Plant Mol. Biol. 32:565-569.

Chang, S.M., Y. Lu, and M.D. Rausher. 2005. Neutral evolution of the non-binding region of the anthocyanin regulatory gene Ipmyb1 in Ipomoea. Genetics 170:1967-1978.

Collette, V.E. 2002. A molecular analysis of flower color development in an ornamental monocot (Anthurium andraeanum). Massey University, Palmerston North, New Zealand. PhD Diss.
Collette, V.E., P.E. Jameson, K.E. Schwinn, P. Umaharan, and K.M. Davies. 2004. Temporal and spatial expression of flavonoid biosynthetic genes in flowers of Anthurium andraeanum. Physiol. Plant. 122:297-304.

Cone, K.C., F.A. Burr, and B. Burr. 1986. Molecular analysis of the maize anthocyanin regulatory locus C1. Proc. Natl. Acad. Sci. USA 83:9631-9635.

Cone, K.C., S.M. Cocciolone, F.A. Burr, and B. Burr. 1993. Maize anthocyanin regulatory gene $\mathrm{pl}$ is a duplicate of $\mathrm{c} 1$ that functions in the plant. Plant Cell 5:1795-1805.

Dooner, H.K., T.P. Robbins, and R.A. Jorgensen. 1991. Genetic and developmental control of anthocyanin biosynthesis. Annu. Rev. Genet. 25:173-199.

Ehrenberger, J. and A.R. Kuehnle. 2003. Enhanced histological technique for observation of spathe pigmentation in Anthurium species and hybrids. Aroideana 26:120-124.

Goodrich, J., R. Carpenter, and E.S. Coen. 1992. A common gene regulates pigmentation pattern in diverse plant species. Cell 68:955-964.

Grotewold, E., M.B. Sainz, L. Tagliani, J.M. Hernandez, B. Bowen, and V.L. Chandler. 2000. Identification of the residues in the Myb domain of maize $\mathrm{C} 1$ that specify the interaction with the bHLH cofactor R. Proc. Natl. Acad. Sci. USA 97:13579-13584.

Higaki, T., J.S. Lichty, and D. Moniz. 1994. Anthurium culture in Hawaii. HITAHR Res. Ext. Ser. 152.

Higaki, T., H.P. Rasmusan, and W.J. Carpenter. 1984. A study of some morphological and anatomical aspects of Anthurium andraeanum Lind. HITAHR Res. Ext. Ser. 030:1-12.

Iwata, R.Y., C.S. Tang, and H. Kamemoto. 1979. Anthocyanins of Anthurium andraeanum Lind. J. Amer. Soc. Hort. Sci. 104:464-466.

Iwata, R.Y., C.S. Tang, and H. Kamemoto. 1985. Concentration of anthocyanins affecting spathe color in anthuriums. J. Amer. Soc. Hort. Sci. 110:383-385.

Jaakola, L., K. Määttä, A.M. Pirttilä, R. Törrönen, S. Kärenlampi, and A. Hohtola. 2002. Expression of genes involved in anthocyanin biosynthesis in relation to proanthocyanidin, and flavonol levels during bilberry fruit development. Plant Physiol. 130:729-739.

Kamemoto, H., R.Y. Iwata, and M. Marutani. 1988. Genetics of the major spathe colors in anthuriums. HITAHR Res. Ext. Ser. 056: $8-88$.

Kamemoto, H. and A.R. Kuehnle. 1996. Breeding anthuriums in Hawaii. Univ. Hawaii Press, Honolulu, HI.

Kamemoto, H. and H.Y. Nakasone. 1955. Improving anthuriums through breeding. Hawaii Farm Sci. 3:4-5.

Kamemoto, H. and H.Y. Nakasone. 1963. Evaluation and improvement of anthurium clones. Hawaii Agr. Exp. Sta. Tech. Bull. 58.

Kamemoto, H., H.Y. Nakasone, and M. Aragaki. 1968. Improvement of anthuriums through breeding. Proc. Trop. Reg. Amer. Soc. Hort. Sci. 12:267-273

Kondo, S., M. Maeda, S. Kobayashi, and C. Honda. 2002. Expression of anthocyanin biosynthetic genes in Malus sylvestris L. 'Mutsu' non-red apples. J. Hort. Sci. Biotechnol. 77:718-723.

Park, K.I., J.D. Choi, A. Hoshino, Y. Morita, and S. Iida. 2004. An intragenic tandem duplication in a transcriptional regulatory gene for anthocyanin biosynthesis confers pale colored flowers and seeds with fine spots in Ipomoea tricolor. Plant J. 38:840-849.

Quattrocchio, F., J.F. Wing, H.T.C. Leppen, J.N.M. Mol, and R.E. Koes. 1993. Regulatory genes controlling pigmentation are functionally conserved among plant species and have distinct sets of target genes. Plant Cell 5:14971512.

Sablowski, R.W.M., E. Moyano, F.A. CulianezMacia, W. Schuch, C. Martin, and M. Bevan. 1994. A flower specific myb gene activates transcription of phenylpropanoid biosynthetic genes. EMBO J. 13:128-137.

Tuerck, J.A. and M.E. Fromm. 1994. Elements of the maize A1 promoter required for transactivation by the anthocyanin $\mathrm{B} / \mathrm{C} 1$ or phlobaphene $\mathrm{P}$ regulatory genes. Plant Cell 6:1655-1663.

Van Herk, I.M., I.M. van Koppen, I.S. Smeding, I.C. van der Elzen, N. van Rosmalen, I.J. van Dijk, I.A. Lont, and I.J. van Spingelen. 1998. Cultivation guide anthurium. Anthura, Bleiswijk, The Netherlands.

Wannakrairoj, S. and H. Kamemoto. 1990. Inheritance of purple spathe in anthurium. J. Amer. Soc. Hort. Sci. 115:169-171.

Williams, C.A., J.B. Harborne, and S.J. Mayo. 1981. Anthocyanin pigments and leaf flavonoids in the family Araceae. Phytochemistry $20: 217-234$. 